\title{
The Futhark in Oregon: an Excursus on Collegiate Onomastics
}

\section{WALTER C. KRAFT}

\section{$\mathrm{V}$}

isitors to the Willamette Valley in Oregon may be somewhat dismayed at certain inscriptions and names which only recently have been unearthed on the campus of Oregon State University (OSU). ${ }^{1}$ Here, for all to behold, are to be found dwelling halls - each with its own appropriate runic inscription - bearing such names as the following:

$\begin{array}{lll}\text { Auer Beork } & \text { Kaun Ilix } & \text { Sigel Hagall } \\ \text { Ehr Staan } & \text { Kaun Raad } & \text { Thorn Tyr } \\ \text { Gar Ilix } & \text { Kaun Staan Ilix } & \text { Tyr Feoh Kaun } \\ \text { Gar Tyr } & \text { Naud Ilix } & \text { Tyr Ilix Gar } \\ \text { Gar Wyn } & \text { Naud Kaun } & \text { Wyn Thorn } \\ \text { Hagall Staan } & \text { Othil Gar } & \text { Wyn Tyr } \\ \text { Ilix Ilix Ilix } & \text { Quorth Logar } & \text { Yar Ilix Yar } \\ \text { Kaun Eis } & \text { Quorth Staan } & \text { Yar Yar Logar }\end{array}$

It is not to be inferred that these inscriptions and names were left behind by certain ancient Norse wayfarers who somehow made their way from Greenland to Markland and thence to the Pacific Coast by way of Hudson Bay and Minnesota; the curious reader will look in vain for any such trek in The Norse Discoveries and Explorations in America. ${ }^{2}$ Nor, when the visitor hears such a refrain as "Ye men of Hagall Staan, arise!" chanted within these halls, is he to assume that this is some latter-day version of a song first sung by an ancient scop or skald which somehow eluded the able editors of the Corpus Poeticum Boreale ${ }^{3}$ or The Anglo-Saxon Poetic Records. ${ }^{4}$

\footnotetext{
1 Nomina mutantur - by recent legislative action the name Oregon State College was changed to Oregon State University, effective August 9, 1961 - et nos mutamur in illis.

2 Edward Reman (Berkeley and Los Angeles, 1949).

3 Gudbrand Vigfusson and F. York Powell, edd. (Oxford, 1883).

4 G. P. Krapp and E. V. K. Dobbie, eds. (New York, 1931 ff.).
} 
A far simpler explanation for the occurrence of such proud and high-sounding names on the Pacific slope of North America is to be offered. Several years ago a student came to me and inquired as to the feasibility of devising a new system of names that might be used in designating the various men's residence halls here at Oregon State University, saying that he had been assigned to a student committee to study the situation and to make recommendations for a new system. He pointed out that heretofore the names of persons had widely been used in formulating names for such halls; he also recalled that in the United States the names of the letters of the Greek alphabet had been used long and extensively to designate various college and university organizations. He then asked if I could suggest some other alphabet which might serve the same purpose but which would be more novel in the business of collegiate name-giving.

When I suggested the futhark, he exclaimed, "Futhark! What's that?" Thereupon I took down a copy of Handbuch der Runenkunde and told him that he would find the answer to his question therein. He took the book, thanked me, and departed. Some weeks later he returned the book, saying that he had perused it duly and that he had devised a system which he intended to recommend for adoption. Thereupon he departed a second time.

Considerable time elapsed, and I thought nothing more of the incident. Shortly after the beginning of the next school year, however, an article appeared in the college newspaper announcing that a new system for naming the men's residence halls had been devised and adopted; in the article, too, a brief explanation of the word rune was given, and the symbols also were shown with their names transliterated into the roman alphabet. ${ }^{6}$ Later, when talking with my young friend again, I asked him how he and his committee had come to settle upon the names which they finally selected for the local futhark. To this he replied that they had arbitrarily chosen names from the various runic alphabets which they had found recorded, and these - both symbol and name - they had altered here

5 Helmut Arntz (Halle/Saale, 1935). - Sometime after this episode occurred, a small book appeared in English which reviews the subject briefly but adequately: R. W. V. Elliott, Runes: An Introduction (New York, 1959).

6 "Germanic Names Are Given to Clubs in Men's Dorms," Oregon State College Daily Barometer (Corvallis, Oregon), Sept. 25, 1957, p. 4. 
and there to suit their fancy. Their chief concern, besides novelty, was that the symbols should be distinctive and that the names therefor should not easily be confused with other English words and names.

Whereas the common Germanic futhark consisted of 24 runes, the futhark employed on this campus consists of 27 names and symbols respectively, corresponding in the main to the 29-rune futhark as revealed in the Old English Rune Poem ${ }^{7}$ (with several runes taken from the expanded Old English futhark of 33 runes) rather than to the reduced Scandinavian futhark of 16 characters. It is interesting to note that while most of the runic names employed locally are of Old English origin, several of them are basically Old Norse; the local runic symbols, moreover, are in most instances historically accurate. ${ }^{8}$

For purposes of comparison a table is furnished herewith showing the normalized names of the expanded Old English futhark together with those of the reduced Old Norse futhark; in addition, the names of the runes as adopted locally are listed together with the meanings most commonly accepted for all. ${ }^{9}$

$\begin{array}{llll}O E & O N & O S U & \text { Meaning } \\ \text { 1. feoh } & \text { fé } & \text { feoh } & \text { cattle, wealth } \\ \text { 2. ūr } & \text { úrr } & \text { auer } & \text { aurochs } \\ \text { 3. porn } & - & \text { thorn } & \text { thorn } \\ - & \text { purs } & - & \text { ogre } \\ \text { 4. ōs } & \text { óss } & - & \text { river mouth; god } \\ \text { 5. rād } & \text { reið } & \text { raad } & \text { ride, journey } \\ \text { 6. cēn } & - & - & \text { torch } \\ - & \text { kaun } & \text { kaun } & \text { ulcer } \\ \text { 7. giefu } & - & - & \text { gift } \\ \text { 8. wynn } & - & \text { wyn } & \text { joy } \\ \text { 9. hægl } & \text { hagl } & \text { hagall } & \text { hail } \\ \text { 10. nied } & \text { nauð(r) } & \text { naud } & \text { need } \\ \text { 11. is } & \text { íss } & \text { eis } & \text { ice }\end{array}$

7 Bruce Dickins, Runic and Heroic Poems of the Old Teutonic Peoples (Cambridge, 1915), pp. 12-23.

8 See The Beaver. Published by the Associated Students of Oregon State College/ University. (Corvallis, Oregon), vols. 52-56 (1958-62), passim.

${ }^{9}$ Cf. Elliott, Runes, pp. 48-49. - Karl Schneider, Die germanischen Runennamen. Versuch einer Gesamtdeutung (Meisenheim am Glan, 1956), passim. 
$O E$

12. gēar

13. ēoh, ēow

14. peorð

15. eolhx, ilix

16. sigel

17. tīr

18. beorc

19. eoh, hæc

20. mann

21. lagu

22 . ing

23. dæg

24. ēðel, ōðel

25. $\overline{\mathrm{ac}}$

26. æsc

27. $\overline{\mathrm{y}} \mathrm{r}$

28. ior

29. ear

30. cweorð

31. calc

32. stān

33. gār
$O N$

ár

ýr

-

-

sól

týr

bjarkan

-

maðr

lögr
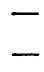

$-$
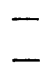

-
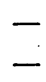

$-$

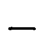

$-$
$O S U$

yeer

yar

perk

ilix

sigel

tyr

beork

haec

mann

logar

engg

daeg

othil

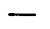

asck

-

$-$

ehr

quorth

-

staan

gar
Meaning

year

yew

(?)

sedge

sun

the god Tyr

birch

horse

man

sea, water

the god Ing

day

homeland

oak

ash tree

yew bow

sea (?)

(?)

cup

stone

spear

A final word remains to be said. The system of name-giving as here described has been widely accepted by the students of this institution; every year new organizations are founded, and every year new names are added to the list. When one reads Tri-Ilix in the student newspaper for Ilix Ilix Ilix, one feels that the new system has definitely been accepted by the university community. Having found acceptance on this campus for over four years, the futhark bids fair to persist indefinitely.

Oregon State University, Corvallis 


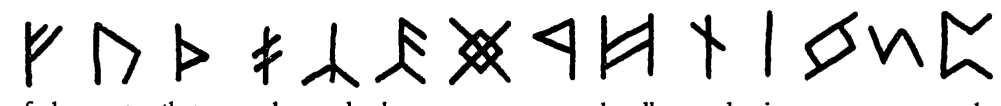

The Runic Alphabet

Runes (the Futhark) are the native Germanic form of the alphabet, and the earliest go back in date to about the second century A.D. The name "rune" means mystery, secret, and shows the sense of mystery which was attached to the infancy of writing everywhere. The great majority of the inscriptions have been found in Scandinavia, Great Britain, and Germany. Since the symbols were made by cutting in wood or stone, the shape of the signs is angular and free from curves. Eventually Runes gave way to the Latin alphabet as the Church of Rome extended its influence.

The use of the Runic Alphabet to name men's living groups in the dormitories at Oregon State arose from a desire to have distinct names, and to allow for future expansion. The present use of the alphabet was developed by members of a committee established by the Inter-Dormitory Council. It was accepted by residents of the dormitories and approved by the Council.

These letters are pronounced almost exactly as spelled. When you try, it is easy.

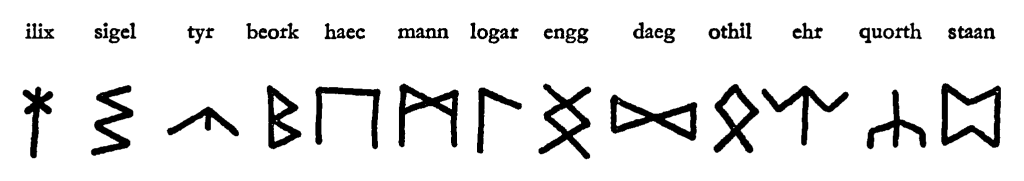

Brochure Publicizing New System of Names 